PLPB : Pendidikan Lingkungan dan Pembangunan Berkelanjutan

DOI : http://doi.org/10.21009/PLPB.211.02

DOI : 10.21009/PLPB

\title{
PENGARUH STRATEGI PEMBELAJARAN METAKOGNITIF TERHADAP KEMAMPUAN MEMECAHKAN MASALAH LINGKUNGAN DALAM PEMBELAJARAN SAINS
}

\author{
Tina $^{1}$, Budiaman $^{2}$, Uswatun Hasanah $^{3}$ \\ Pendidikan Lingkungan Pascasarjana Universitas Negeri Jakarta \\ Jl. Rawamangun Muka, Jakarta Timur, Indonesia 13220 \\ Email: ${ }^{1}$ tina_pklh2017@mahasiswa.unj.ac.id ${ }^{2}$ budiaman@unj.ac.id $^{3}{ }^{\text {uswatun-hasanah@unj.ac.id }}$
}

\begin{abstract}
Sains is knowledge which universal and sistematic, also a collective knowledge of facts and concepts. In this research was given a metacognitive strategies to student's environmental problem solving in science learning. This research was aimed to find the effect of metacognitive strategies to student's environmental problem solving in science learning. The population of this research was Kartika X-1 Junior High School's students, and the sample were the seventh grade classes which randomly chosen. The data was collected by giving questionnaire about student's ability of environmental problem solving for both of contol and experiment classes. The result were showed that the post-test average score of experiment class higher than the control class as much 34,37 > 24,00. The t-test showed that the result was significant at 0,000 >0,005 which means that the metacognitive strategies give positive effect to student's environmental problem solving in science learning.
\end{abstract}

Key words: metacognitive strategies, environmental problem solving, science learning

Abstrak

Sains merupakan ilmu pengetahuan yang bersifat universal dan sistematis, juga merupakan kumpulan pengetahuan berupa fakta-fakta maupun konsep. Dalam penelitian ini diberikan pengaruh strategi metakognitiif terhadap kemampuan memecahkan masalah lingkungan siswa dalam pembelajaran sains. Tujuan penelitian ini adalah untuk mengetahui pengaruh strategi metakognitiif terhadap kemampuan memecahkan masalah lingkungan oleh siswa dalam pembelajaran sains. Populasi dalam penelitian ini adalah seluruh siswa SMP Kartika X-1 dan sampelnya adalah seluruh siswa kelas tujuh yang terpilih secara acak. Data diperoleh dengan memberikan kuesioner post-test mengenai kemampuan pemecahan masalah lingkungan terhadap kelas kontrol dan eksperimen. Hasil penelitian menunjukkan bahwa rata-rata skor post-test kelas eksperimen lebih tinggi dibandingkan kelas kontrol yaitu sebesar 34,37 > 24,00. Uji-t menunjukkan bahwa terdapat hasil yang signifikan yaitu 0,000 > 0,005 yang berarti bahwa strategi metakognitiif positif memberikan pengaruh terhadap kemampuan memecahkan masalah lingkungan siswa dalam pembelajaran sains.

\begin{tabular}{|c|c|c|c|}
\hline Volume XXI & Nomor 1 & Maret 2020 & e-ISSN : 2580-9199 \\
\hline
\end{tabular}


Kata kunci: strategi metakognitiif, pemecahan masalah lingkungan, pembelajaran sains

\section{PENDAHULUAN}

Sains atau IPA didefinisikan sebagai pengetahuan yang sistematis dan tersusun secara teratur, berlaku umum (universal), dan berupa kumpulan data hasil observasi dan eksperimen. Sains bersifat dinamis atau selalu mengalami perkembangan dan bertambah setiap saat, sehingga dengan

mempelajari sains berarti secara tidak langsung mengikuti perkembangan jaman. Pembelajaran sains menekankan pada pemberian pengalaman secara langsung untuk mengembangkan kompetensi agar memahami alam sekitar secara ilmiah.

Sains merupakan ilmu yang berkaitan dengan cara mencari tahu tentang gejala alam secara sistematis, sehingga sains bukan hanya penguasaan kumpulan pengetahuan yang berupa fakta-fakta, konsep-konsep atau prinsip-prinsip saja tetapi juga merupakan suatu proses penemuan (BSNP, 2006).

Terdapat lima ranah dalam pendidikan atau pembelajaran sains yaitu Pertama, knowing and understanding (knowledge domain), termasuk: fakta, konsep, hukum (prinsip-prinsip), beberapa hipotesis dan teori yang digunakan para saintis, dan masalah-masalah sains dan sosial. Kedua, exploring and discovering (process of science domain), yakni penggunaan beberapa proses sains untuk belajar bagaimana para saintis berpikir dan bekerja. Ketiga, imagining and creating (creativity domain), yakni kemampuan berimajinasi, serta menghasilkan ide-ide yang luar biasa. Keempat, feeling and valuing (attitudinal domain), yang mencakup pengembangan sikap positif terhadap diri sendiri, pengembangan kepekaan, serta pengambilan keputusan tentang masalahmasalah lingkungan dan sosial. Kelima, using and applying (application and connection domain). Kelima, using and applying (application and connection domain) (McCornack, Allan J. \& Yager, Robert E., 1989 dalam Zubaidah, 2011).

Sains dapat diartikan sebagai konstruksi pengetahuan (body of knowledge) yang muncul dari pengelompokkan secara sistematis dari berbagai penemuan ilmiah sejak jaman dahulu, atau bisa disebut sains sebagai produk. Produk yang dimaksud adalah gfakta-fakta, prinsip-prinsip, modelmodel, hukum-hukum alam, dan berbagai teori yang membentuk semesta pengetahuan. Sains juga dapat juga berarti metoda khusus untuk memecahkan masalah, atau juga biasa disebut dengan sains sebagai proses.

Hakikat pembelajaran sains adalah melatih siswa berproses aktif dalam berpikir dan bersikap ilmiah terhadap objek atau 
fenomena alam yang sedang dipelajari untuk kemudian dicari permasalahannya hingga mampu menggunakan kemampuan dalam memecahkan masalah menggunakan metode ilmiah. Sehingga guru diharapkan mampu menggunakan metode ataupun strategistrategi pembelajaran yang dapat mendorong peningkatan kemampuan pemecahan masalah oleh siswa.

Pemberian masalah selama proses belajar berlangsung dapat memberikan kesempatan kepada siswa dalam membangun konsep pengetahuannya sendiri, mengatur strategi penyelesaian masalah dan melatih kemampuan serta kemandirian dalam belajar. Setidaknya ada lima aspek kemampuan yang harus dikuasai oleh siswa yaitu : (1) kemampuan tentang konsep sains, (2) kemampuan dalam menguasai keterampilan sains, (3) kemampuan proses dalam memahami sains, (4) kemampuan untuk bersikap positif terhadap sains, dan (5) kemampuan metakognitif.

Metakognitif dapat secara bebas didefinisikan sebagai "berpikir mengenai cara bepikir seseorang." Secara sepesifik, metakognitif adalah "apresiasi terhadap apa yang diketahui seseorang, bersamaan dengan pengertian yang benar dari tugas pembelajaran dan pengetahuan apa dan keterampilan yang dibutuhkan, dikombinasikan dengan kemampuan membuat kesimpulan mengenai bagaimana mengaplikasikan pengetahuan strategik seseorang dalam situasi tertentu secara efisien dan reliabel (Pierce, 2003).

Ranah kategori kognitif dibagi menjadi dua jenis yaitu: strategi metakognitif dan strategi kognitif (O’Malley \& Chamot, 1990 dalam Mehrak, Rahimi \& Mahral Katal, 2011). Strategi metakognitif melihat, mengarahkan dan meregulasi proses pembelajaran. Strategi jenis ini melibatkan berpikir mengenai proses pembelajaran, merencanakan, memonitori, dan mengevaluasi pembelajaran. Sedangkan strategi kognitif memanipulasi bahan untuk dipelajari atau diaplikasikan dengan teknik spesifik dalam tugas pembelajaran. Dasar strategi metakognitif meliputi menghubungkan informasi baru ke dalam informasi lama, menseleksi strategi belajar yang tepat, dan merencanakan, memonitori dan mengevaluasi proses berpikir (Oxford, 2002).

Interaksi antara strategi pembelajaran dengan gaya berpikir berpengaruh terhadap tinggi rendahnya kemampuan siswa memecahkan masalah lingkungan (Budiaman, 2015). Dalam strategi metakognitif, siswa melakukan observasi dan investigasi sebelum menyelesaikan masalah dengan mengembangkan rencana, monitoring, dan mengevaluasi cara belajar dan berpikir mereka sendiri; pendekatan ini dapat meningkatkan efisiensi penyelesaian 
masalah oleh siswa (Suriyon \& Sangaroon, 2013).

Terdapat lima tingkatan pemecahan masalah menurut Dewey yaitu : (1) menghadapi masalah (confront problem), yaitu menyadari kesulitan yang dialami meliputi hal yang belum diketahui; (2) pendefinisian masalah (define problem), yaitu mengklarifikasi karakteristikkarakteristik kondisi, mengidentifikasi situasi; (3) penemuan solusi (inventory several solution), yaitu menganalisis polapola, mengidentifikasi langkah-langkah dalam perencanan; (4) konsekuensi dugaan solusi (conjecture consequence of solution), yaitu melakukan perencanaan atas dugaan; (5) menguji konsekuensi (test consequences), yaitu menguji apakah definisi masalah cocok dengan situasinya (Dewey, 2005 dalam Carson, J., 2007).

Berdasarkan beberapa hal diatas, maka penelitian ini bertujuan untuk mengetahui pengaruh penerapan strategi pembelajaran metakognitif terhadap kemampuan pemecahan masalah siswa dalam pembelajaran sains.

Berdasarkan hal di atas, maka dapat dirumuskan beberapa permasalahan sebagai berikut:

1. Bagaimana meningkatkan kemampuan pemecahan masalah lingkungan siswa dalam pembelajaran sains ?
2. Bagaimana pengaruh strategi pembelajaran metakognitif terhadap kemampuan pemecahan masalah lingkungan siswa dalam pembelajaran sains ?

\section{METODE PENELITIAN}

\section{Lokasi dan Waktu Penelitian}

Penelitian ini dilakukan di SMP Kartika X-1 Jakarta. Penelitian ini dilakukan pada bulan Februari 2019.

\section{Metode Pengambilan Sampel dan Data}

Jenis penelitian ini adalah penelitian quasi-eksperimen dengan post-test only design. Metode pengumpulan data penelitian meliputi metode tes yang digunakan untuk memperoleh data kemampuan pemecahan masalah siswa. Sebelumnya, data kemampuan pemecahan masalah matematika dilakukan uji prasyarat meliputi uji normalitas populasi menggunakan metode Lilliefors dan uji homogenitas. Selanjutnya dilakukan uji-t untuk membuktikan hipotesis dengan taraf signifikansi $\alpha=0.05$.

Populasi penelitian ini adalah seluruh siswa SMP Kartika X-1 Jakarta Timur. Sampel penelitian ini adalah siswa kelas VII yang ditentukan dengan teknik simple random sampling. Jumlah sampel yang diambil dalam penelitian ini adalah sebanyak 30 orang.

HASIL DAN PEMBAHASAN 
Setelah dilakukan penelitian, maka diperoleh data rata-rata post-test serta deskripsi data kemampuan pemecahan masalah siswa.

Tabel 1. Hasil Uji Normalitas

\begin{tabular}{lllll} 
& Kelompok & Statistik & df & ig. \\
\hline Kemampu & Eksperimen & 164 & 3 & .03 \\
an & & & 0 & 9 \\
memecah & Kontrol & .132 & 3 & .19 \\
$\begin{array}{l}\text { kan } \\
\text { masalah }\end{array}$ & & & 0 & 6 \\
\hline \multicolumn{1}{r}{ Uji } & normalitas & menunjukkan & data
\end{tabular}
berdistribusi tidak normal karena ada nilai $\alpha<$ 0.05 di salah satu kelompok yaitu 0.039 (kelompok eksperimen) dan 0.196 (kelompok kontrol)

Tabel 2. Uji Beda 2 Kelompok (Mann-Whitney)

\begin{tabular}{ll} 
& $\begin{array}{l}\text { Kemampuan } \\
\text { memecahkan } \\
\text { masalah }\end{array}$ \\
\hline Mann-Whitney U & .500 \\
Wilcoxon W & 465.500 \\
Z & -6.668 \\
Asymp. Sig (2-tailed) & .000 \\
\hline
\end{tabular}

Terdapat perbedaan signifikan antara kelompok eksperimen dan kontrol $(\alpha<0.05$, yaitu 0.000).

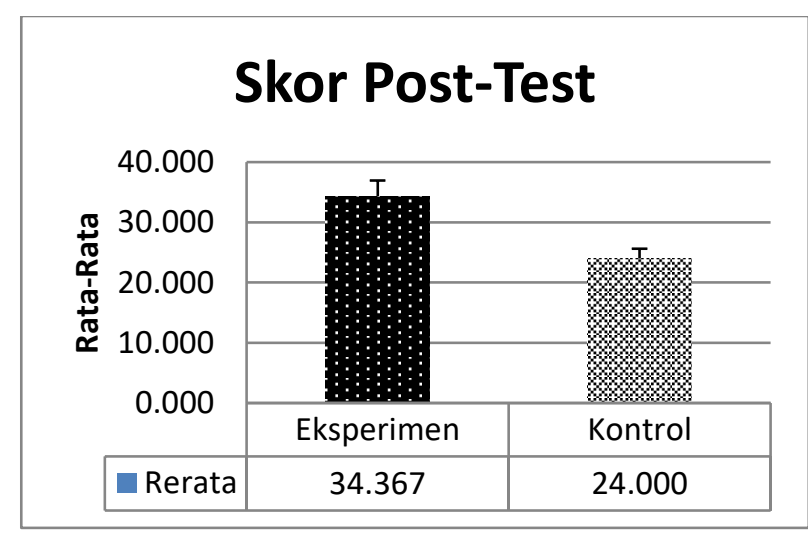

Gambar 1. Rata-Rata Skor Post-Test

\section{Aspek Pemecahan Masalah}

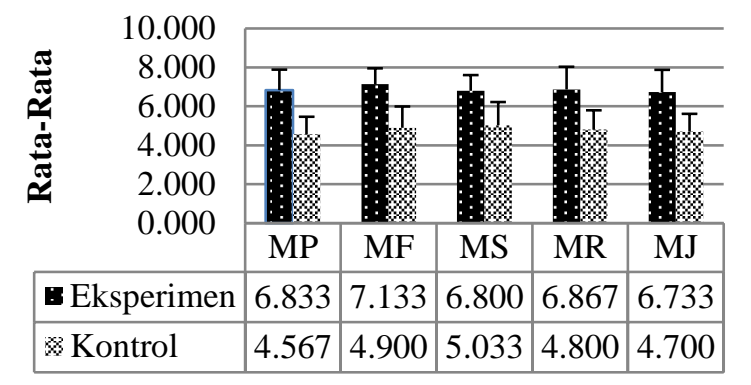

Gambar 2. Perbandingan Aspek Pemecahan Masalah

\section{PEMBAHASAN}

Berdasarkan hasil diatas diketahui bahwa rerata skor post-test kelas eksperimen lebih besar dibandingkan kelas kontrol, yaitu sebesar 34,367 > 24,00. Data uji-t pada tabel 2 di atas diperoleh sig. kesamaan dua ratarata adalah dari sig.(2-tailed) yaitu 0,000 < 0,05 sehingga $\mathrm{H}_{0}$ ditolak. Artinya bahwa terdapat perbedaan rata-rata postest kemampuan pemecahan masalah siswa antara kelas eksperimen dan kelas kontrol. Dapat disimpulkan bahwa kemampuan akhir pemecahan masalah siswa antara kelas eksperimen dan kelas kontrol adalah berbeda secara signifikan.

Tahap pelaksanaan pembelajaran pada kelas kontrol dan kelas eksperimen dilakukan dengan memberi perlakuan yang berbeda pada dua kelas tesebut. Perbedaan tampak pada kelas eksperimen yang diterapkan strategi metakognitif.

$$
\text { Kegiatan metakognitif meliputi }
$$
kegiatan berfikir untuk merencanakan,

\begin{tabular}{|l|l|l|l|}
\hline Volume XXI & Nomor 1 & Maret 2020 & e-ISSN : 2580-9199 \\
\hline
\end{tabular}


memonitoring, merefleksi bagaimana menyelesaikan suatu masalah (Livingston, J.A, 1997). Pembelajaran dengan pendekatan keterampilan metakognitif sebagai pembelajaran yang menanamkan kesadaran bagaimana merancang, memonitor, serta mengontrol tentang apa yang mereka ketahui; apa yang diperlukan untuk mengerjakan dan bagaimana melakukannya (Suzanna, 2004). Pembelajaran dengan pendekatan metakognitif menitikberatkan pada aktivitas belajar siswa; membantu dan membimbing siswa jika ada kesulitan; serta membantu siswa untuk mengembangkan konsep diri apa yang dilakukan saat belajar matematika.

Saat ini, guru dalam mengevaluasi pencapaian hasil belajar cenderung hanya memberikan penekanan pada tujuan kognitif tanpa memperhatikan proses kognitif, khususnya pengetahuan metakognitif dan keterampilan metakognitif. Akibatnya upaya-upaya untuk memperkenalkan metakognitif dalam menyelesaikan masalah kepada siswa sangat kurang atau bahkan cenderung diabaikan (Putra, I., 2012).

Untuk kesuksesan penyelesaian suatu masalah yang kompleks diperlukan variasi proses metakognitif. Seorang problem solver yang sukses menyadari bahwa mereka dapat memandu usahanya dengan mencari dan mengenali langkah yang sebelumnya dilakukan dengan mengkombinasikan dan mengkoneksikan informasi antara pengetahuan yang lalu dengan situasi masalah. Semakin sedikit pengalaman seorang problem solver maka ia tidak bisa memonitor proses penyelesaiannya secara efektif, walaupun mereka dapat melanjutkan proses penyelesaian masalah namun mungkin strategi yang digunakan salah. Pengaturan metakognitif terjadi ketika individu menggunakan keterampilan metakognitifnya untuk mengarahkan pengetahuan dan pemikiran mereka. Pengaturan metakognitif menggambarkan pengetahuan individu (tentang diri sendiri dan strategi, termasuk bagaimana dan mengapa mereka menggunakan strategi tertentu) dan menggunakan keterampilan eksekutif (seperti perencanaan, koreksi diri sendiri, menentukan tujuan) ke pengoptimalan pemakaian sumber daya kognitifnya.

Strategi pembelajaran metakognisi dapat menjadikan siswa belajar lebih terarah dan mandiri. Hal ini disebabkan karena siswa belajar dari memahami masalah, memilih informasi pengetahuan, memilih strategi, sampai pada penyelesaian masalah dengan benar. Selain itu juga, siswa dituntut untuk memonitor proses pemecahan masalah, mengevaluasi proses penggunaan strategi dan kebenaran penggunaannya, sampai masalah dipecahkan dengan benar. Strategi pembelajaran metakognisi juga dapat membantu siswa untuk lebih memahami 
konsep dan dapat memonitor aktivitas berpikir mereka.

Teori strategi metakognitif dari Flavell dan Brown terdapat 3 komponen yang digunakan yaitu perencanaan diri (selfplanning), pemantauan diri (self-monitoring), dan penilaian diri (self-evaluation). Siswa yang mampu merencanakan perkiraan waktu yang diperlukan untuk menyelesaikan tugas, mengorganisasi materi, dan mengambil langkah yang tepat dalam belajar adalah siswa yang sadar akan kemampuannya. Menurut Rivers (2001) dan Scraw \& Dennison (1994), siswa yang terampil melakukan penilaian terhadap diri sendiri adalah siswa yang sadar akan kemampuannya. Peter (2000) berpendapat keterampilan metakognisi memungkinkan siswa berkembang sebagai pebelajar mandiri, karena siswa didorong menjadi penilai atas pemikiran dan pembelajarannya sendiri. Keterampilan metakognisi diperlukan siswa untuk memahami bagaimana tugas itu dilaksanakan (Rivers, 2001).

Kesuksesan seseorang dalam menyelesaikan pemecahan masalah antara lain sangat bergantung pada kesadarannya tentang apa yang mereka ketahui dan bagaimana mereka melakukannya, sehingga dalam proses pembelajaran fisika harus terjadi keseimbangan antara melakukan (doing) dan berpikir (thinking). Proses berpikir dalam pemecahan masalah merupakan hal penting yang perlu mendapat perhatian para pendidik terutama untuk membantu siswa agar dapat mengembangkan kemampuan memecahkan masalah. Berpikir tentang apa yang dipikirkan erat kaitannya dengan kesadaran siswa terhadap kemampuannya untuk mengembangkan berbagai cara yang mungkin dilakukan dalam memecahkan masalah. Keberhasilan seorang siswa ditentukan oleh pengetahuan, kesadaran, dan kontrol terhadap pengetahuan yang dimiliki oleh siswa.

Terlibatnya metakognisi dalam memecakan masalah maka memungkinkan terbangunnya pemahaman yang kuat dan menyeluruh terhadap masalah disertai alasan yang logis. Oleh karena itu, alangkah lebih baiknya jika seorang guru melibatkan aspek metakognitif, pengetahuan kognitif yaitu pengetahuan yang dimiliki tentang dirinya dan regulasi kognitif yaitu mengacu pada tindakan yang dapat membantu siswa dalam mengatur atau mengendalikan aktivitas kognitifnya.

Siswa tidak bisa menganalisis suatu masalah jika tidak mengenal dan memahami masalahnya. Oleh karena itu, aspek merakognitif sangat penting dalam menunjang kemampuan berpikir analitik siswa tentang masalah lingkungan dikarenakan siswa membutuhkan kemampuan untuk berpikir mengenai apa yang menjadi masalah yang dipikirkannya. 


\section{KESIMPULAN}

Berdasarkan hasil analisis data dan pembahasan maka ditarik kesimpulan bahwa penerapan strategi metakognitif memberikan pengaruh positif terhadap kemampuan pemecahan masalah siswa dalam pembelajaran sains di SMP Kartika X-1.

Hasil penelitian memberikan rekomendasi bahwa pembelajaran yang memperhatikan aspek metakognitif dapat terus dikembangkan dalam memecahkan masalah lingkungan, khususnya dalam pembelajaran sains. Karakter mata pelajaran sains yang terintegrasi diharapkan mampu mengembangkan pola pikir siswa yang berbasis pemecahan masalah.

\section{DAFTAR PUSTAKA}

Badan Standar Nasional Pendidikan. (2006). Lampiran Peraturan Menteri Pendidikan Nasional No 22 Tahun 2006 Tanggal 23 Mei 2006 tentang Standar Isi. Tersedia di https://asefts63.files.wordpress.com /2011/01/permendiknas-no-22tahun-2006-standar-isi.pdf [diakses 15-1-2019].

Budiaman \& Nadiroh. (2015). The Influence Of Learning Strategies And Styles Of Thought On The Ability Of Students To Solve Environmental Problems. Jurnal Pendidikan Lingkungan dan Pembangunan Berkelanjutan, Volume XVI Nomor 02 (September 2015), ISSN 14111829.
Carson, J. M., and Chamot, A. U. (1990). Learning strategies in second language acquisition. New York: Cambridge University Press.

O'Malley, J. M., and Chamot, A. U. (1990). Learning strategies in second language acquisition. New York: Cambridge University Press.

Oxford, R. (2002). Language learning strategies. In R. Carter and D. Nunan (Eds.), The Cambridge guide to teaching English to speakers of other languages (pp. 166-172). Cambridge: Cambridge University Press.

Peters, M. (2000). "Does Constructivist Epistemology Have a Place in Nurse Education?". Journal of Nursing Education 39, No. 4 (April 2000): 166-170.

Putra, I. (2012). Pengembangan Perangkat Model Pembelajaran Metakognitif Berpendekatan Pemecahan Masalah dalam Upaya Meningkatkan Aktivitas dan Prestasi Belajar Matematika Bagi Siswa SMP Kelas VII.

Rivers, W. Summer. (2001). Autonomy at All Cosis. An Ethnography of Metacognitive Self-Assessment and Self-Management among Experienced Language Learners. Modern Language Journal 86 No. 2: 279-290

Schraw, G. \& Dennison, R. S. (1994). Assessing metacognitive Awareness. Contemporary Educational Psychology. P. 460475.

Suriyon, Ariya, Inprashita, Maitree \& Sangaroon, Kiat. (2013). Students' Metacognitive Strategies in the Mathematics Classroom Using 
Open Approach. Psychology 2013, Vol.4, No.7, 585-591.

Suzana, Y. (2004). Pembelajaran dengan Pendekatan Metakognitif untuk Meningkatkan Kemampuan Pemahaman Matematik Siswa SMU. Disajikan pada Seminar Nasional Matematika: Matematika dan Kontribusinya terhadap Peningkatan Kualitas SDM dalam Menyongsong Era Industri dan Informasi, Bandung, 15 Mei 2004.

Zubaidah, Siti. (2011). Pembelajaran Sains (IPA) Sebagai Wahana Pendidikan Karakter. Makalah pada Seminar Nasional II "Mewujudkan Pendidik dan Tenaga Kependidikan yang Profesional" dalam rangka memperingati Hari Pendidikan Nasional tanggal 18 Juni 2011 di Pekanbaru. 